\title{
METAFORA BANJIR, GEMPA, DAN LETUSAN GUNUNG (KAJIAN LINGUISTIK ANTROPOLOGIS)
}

\author{
METAPHORS OF FLOODS, EARTHQUAKE, \\ AND VOLCANIC ERUPTION \\ (AN ANTHROPOLOGICAL LINGUISTICS STUDY)
}

\author{
Riani \\ Balai Bahasa Provinsi Daerah Istimewa Yogyakarta \\ I Dewa Nyoman Oka No. 34, Yogyakarta \\ Pos-el: tehriani@gmail.com
}

\begin{abstract}
This study aims to describe the use of metaphors of flood, earthquake, and volcanic eruption and how they reflect the people's mindset on one of natural disasters. This is a qualitative research. The data presented are obtained through observation of the use of metaphoric words of flood, earthquake, and volcanic eruption on television and internet from January to March 2013. The data are then analyzed by using metaphor and anthropological linguistic theory. The results of research show that the uses of metaphors of flood, earthquake, and mount eruption have been mostly used in news. One example is indicated in news report "flood paralyzed capital streets, volcanic eruption had killed many victims and earthquake destroyed several old buildings. Flood, volcanic eruption, and earthquake are likened to living things that can cause a variety of disadvantages, namely crippling, killing, and destroying buildings". Viewed from the practical use of metaphor in society, the uses of metaphors of natural disasters (flood, volcanic eruption, and earthquake) reflect the tremendous effect of which on people's lives, so that they are identically related to the losses in people's lives.
\end{abstract}

Keywords: metaphor, floods, earthquake, volcanic eruption, natural disaster

\begin{abstract}
Abstrak
Penelitian ini untuk mendeskripsikan penggunaan metafora banjir, gempa, dan letusan gunung dan bagaimana penggunaan metafora banjir, gempa dan letusan gunung mencerminkan cara pandang masyarakat terhadap salah satu bencana alam tersebut. Penelitian ini merupakan penelitian kualitatif karena data dan cara penyajian data berupa kata-kata. Seluruh data yang disajikan didapatkan dari pengamatan penggunaan metafora kata banjir, gempa, dan letusan gunung pada media masa baik televisi dan internet yang memuat pemberitaan bencana banjir, gempa, dan letusan Gunung Merapi bulan Januari - Maret 2013. Data dianalisis dengan menggunakan teori metafora dan linguistik antropologi. Dari hasil penelitian tampak bahwa penggunaan metafora pada berita banjir, gempa, dan letusan gunung banyak digunakan, misalnya banjir melumpuhkan jalanan ibukota, letusan Merapi memakan banyak korban, dan gempa menghancurkan beberapa bangunan tua. Banjir, letusan gunung, dan gempa diibaratkan seperti makhluk hidup yang dapat menyebabkan berbagai kerugian, yaitu melumpuhkan, memakan korban, dan menghancurkan
\end{abstract}


bangunan. Ditinjau dari sudut pandang pemakaian metafora dalam masyarakat menunjukkan bahwa penggunaan metafora bencana alam (banjir, gunung meletus, dan gempa) mencerminkan aktivitas bencana alam memiliki kuasa yang besar terhadap kehidupan masyarakat sehingga bencana alam diidentikkan dengan kerugian dalam kehidupan masyarakat.

Kata kunci: metafora, banjir, gempa, letusan gunung, bencana alam

\section{Pendahuluan}

Pemakaian metafora dalam pemberitaan bukanlah hal yang baru. Beberapa penelitian yang membahas penggunaan metafora dalam pemberitaan, misalnya penelitian Lati (2013) dan Satriyo (2008). Kedua penelitian ini membahas penggunaan metafora dalam pemberitaan olahraga, khususnya dalam berita olahraga sepak bola. Selain itu, metafora juga digunakan dalam menyampaikan peristiwa bencana alam banjir, gempa, dan letusan gunung. Pemakaian metafora dalam pemberitaan bencana alam menunjukkan bahwa bencana alam merupakan salah satu bagian penting dalam kehidupan masyarakat Indonesia.

Salah satu sarana dalam memberitakan bencana alam adalah melalui pemakaian metafora. Metafora sebagai salah satu wujud daya kreatif bahasa di dalam penyerapan dan pengungkapan makna. Merunut pada definisinya, metafora adalah sesuatu yang diperbincangkan atau yang hendak diungkapkan dalam tuturan, dan sesuatu diperbandingkan dengannya (Ullman, 2007: 213). Dengan demikian proses penciptaan metafora terjadi ketika pembicara mengandaikan sesuatu yang diperbincangkan dengan sesuatu mempunyai kemiripan dengan cara melakukan perbandingan, seperti pada contoh di bawah ini:
(1) Banjir bandang merupakan salah satu bencana yang sering memakan banyak korban.
(2) Gempa bumi berkekuatan 7,7 Mw di Pangandaran ini membunuh

\section{sedikitnya 20 orang dan menghilangkan 65 orang. \\ (3) Sinabung batuk mengeluarkan awan panas yang menyebabkan 17 orang tewas.}

Pada kalimat (1), (2), dan (3) terdapat metafora, yaitu verba memakan, membunuh, menghilangkan dan batuk. Pemilihan kata kerja yang mengikuti kata banjir, gempa bumi, dan gunung Sinabung dilakukan untuk membuat perbandingan antara bencana banjir, gempa dan letusan gunung dengan kemampuan manusia atau makhluk yang dapat memakan, membunuh, dan batuk.

Penggunaan metafora dalam pemberitaan bencana alam menarik untuk diamati karena metafora digunakan penulis berita sebagai wahana untuk memberitakan peristiwa alam. Metafora dimanfaatkan untuk memberikan kesan imaji terhadap pengalaman-pengalaman indrawi pembuat berita untuk kemudian dikomunikasikan kepada pembaca. Oleh karena itu, tulisan ini bertujuan mendeskripsikan penggunaan metafora kata banjir, gempa, dan letusan gunung dengan menggunakan teori skema imaji. Hasil deskripsi penggunaan metafora kata banjir, gempa, dan letusan gunung diinterpretasikan untuk mendeskripsikan bagaimana metafora banjir, gempa dan letusan gunung mencerminkan cara pandang masyarakat dan pembuat berita terhadap bencana tersebut. 


\section{Teori}

\subsection{Bentuk Metafora}

Kridalaksana (2001: 136) menyatakan bahwa metafora (metaphor) sebagai pemakaian kata atau ungkapan lain untuk objek atau konsep lain berdasarkan kias atau persamaan misalnya, kaki gunung, kaki meja, berdasarkan kias pada kaki manusia. Ullman (2007: 214--217) kemudian membedakan metafora menjadi empat macam, antara lain:

1. metafora autropomorfis (Autropomorphic Metaphors) adalah jenis metafora yang dinamai berdasarkan nama-nama bagian tubuh binatang, atau sebaliknya, nama-nama bagian tubuh manusia dinamai berdasarkan nama bagian tubuh binatang atau benda-benda lain;

2. metafora kehewanan (Animal Metaphors) adalah metafora yang bersumber pada dunia kehewanan. Penamaan ini berdasarkan atas dunia binatang dengan segala sifatnya yang dikenakan kepada manusia yang memiliki sifat-sifat tersebut;

3. metafora konkret ke abstrak (From Concrete to Abstract Metaphors) adalah metafora yang ditimbulkan karena pemindahan pengalaman konkret ke abstrak atau sebaliknya;

4. metafora sinaestesis (Synaesthetic Metaphors) adalah metafora yang diciptakan berdasarkan pengalihan tanggapan indra. Misalnya pengalihan tanggapan dari indra penglihatan ke pendengaran atau sebaliknya, atau pengalihan dari tanggapan indra perasa ke indra pendengaran.

Teori lainnya tentang metafora adalah teori skema imaji yang akan diuraikan pada seperti di bawah ini.

\subsection{Teori Skema Imaji}

Teori skema imaji digunakan untuk mendeskripsikan penggunaan metafora dari pemberitaan banjir, gempa, dan letusan gunung. Teori ini menyatakan bahwa terdapat hubungan antara pengalaman indrawi dengan konsep mental (Lakoff dan Johnson, 2003: 3). Hubungan antara pengalaman indrawi dengan konsep mental tersebut dipetakan melalui unsur. Sumber atau wahana bukanlah dipilih secara acak atau manasuka, melainkan berasal dari pengalaman-pengalaman indrawi. Dengan demikian, konsep metafora merupakan hasil pada induksi dari serangkaian pengalaman. Inilah alasan mengapa tuturan metaforis seringkali lebih lama diingat dibandingkan dengan tuturan biasa.

Lakoff dan Johnson menyebutkan beberapa jenis metafora skema imagi, yaitu orientasi mental (mental orientation), pemikiran ontologis (ontological thinking), dan metafora struktural. Metafora mental orientation dihasilkan dari pengalaman fisik indrawi yang berkaitan dengan orientasi ruang, misalnya atas-bawah, dalam-luar, depanbelakang (Lakoff dan Johnson, 2003: 14). Metafora pemikiran ontologi (ontological thinking) terbentuk melalui metafora konseptual yang mengasosiasikan aktivitas, emosi, ide , dan lain-lain dengan entitas dan substansi yang lain. Metafora ini bertujuan merujuk (reffering), menghitung (quantifying), menunjukkan aspek (identifying aspects), menunjukkan sebab (identifying causes), menunjukkan tujuan dan mendorong tindakan (setting goals and motivating actions), menunjukkan pengaruh (identifying aspect), dan memberikan penilaian (qualifying). Metafora struktural adalah metafora yang terbentuk sebagai elaborasi dari metafora ontologi dan mental orientasi yang mencakup substansi, misalnya dia tahu 
bagaimana mengemas idenya. Ide dalam hal ini diumpamakan sebagai barang yang dibungkus. Lakoff dan Johnson dalam Danesi (1999:166) menyatakan bahwa sebuah metafora tidak berdiri sendiri karena metafora tersebut terbentuk dari ide metafora yang lebih

\section{Konsep Metafora}

\section{Manusia Topics 'Topik'}

Dia

Setiap unsur merupakan bagian dari konsep metafora, manusia sebagai target (topic) dan binatang sebagai sumber karena menampilkan kelas wahana (vehicle) disebut juga medan leksikal.

Saeed (2003:342) menyatakan bahwa bahasa merupakan daerah mental dan kemampuan linguistik didukung oleh bentuk pengetahuan khusus. Pengetahuan khusus menjadi pijakan dalam pembentukan metafora untuk dapat memetakan pola pikir kognitif manusia (Ungerer dan Schimd, 1996:118). Pemetaan ini juga muncul karena manusia memiliki kemampuan untuk memandang dunianya sebagai gambaran dari representasi keberadaan dirinya. Manusia hidup dan berinteraksi dengan lingkungan sekitarnya dan manusia juga belajar dari lingkungan baik yang diturunkan dari nenek moyangnya atau dari lingkungan alam sekitarnya. Kemampuan mencerap berbagai ilmu pengetahuan dari luar dirinya ditujukan untuk memahami bagaimana ia dapat menggunakan bahasa dalam memetakan pengetahuan yang diperolehnya. Cara pandang ini kemudian dimiliki secara bersama-sama oleh sekelompok masyarakat yang lebih lanjut menjadi bagian dari kebudayaan. Cara pandang ini melingkupi pengertian yang dimiliki oleh masyarakat tentang gejala ataupun peristiwa yang berwujud fisik dan umum. Misalnya, metafora dia serigala merupakan bagian dari ide metafora yang lebih besar, yaitu manusia adalah binatang. Konsep Lakoff dan Johnson ini kemudian disebut metafora konseptual. Berikut rumusan dari metafora konseptual: adalah

adalah

\section{Binatang Vehicles 'Wahana'}

serigala abstrak. Pengertian terhadap hal ihwal yang abstrak inilah yang bersifat metaforis. Pengertian ini menjadi metaforis apabila fokusnya meliputi wujud waktu, ruang, proses mental, emosi, nilai moral, pranata sosial dan politik, misalnya metafora konseptual bahasa Inggris seperti time is money. Metafora ini melambangkan kebudayaan yang meletakkan waktu sebagai sesuatu yang sangat berharga senilai uang.

\section{Metode Penelitian}

Metode deskriptif kualitatif digunakan untuk mendeskripsikan bagaimana penggunaan metafora bencana banjir, gunung meletus, dan gempa. Penelitian ini termasuk penelitian kualitatif karena data dan pembahasan analisis menggunakan uraian kata-kata. Data penelitian ini adalah kalimat yang berisi metafora pada beberapa sumber berita media massa yang memuat pemberitaan bencana alam banjir, gunung meletus, dan gempa. Sumber data berupa berita yang diperoleh dari internet, surat kabar, dan televisi selama bulan Januari sampai dengan Maret 2014. Teknik pengumpulan data penelitian ini adalah teknik dokumentasi. Penulis mengobservasi data tertulis dan lisan kemudian membuat dokumentasi dengan cara mencatat data yang mengandung metafora. Prosedur penelitian meliputi: 
1) mengumpulkan data dengan cara mengobservasi untuk kemudian mencatat data yang mengandung metafora; 2) mengklasifikasi dan menyeleksi bentuk metafora menjadi kategori orientasi mental, pemikiran ontologikal, dan metafora struktural; 3) menyajikan dan menginterpretasikan data hasil analisis dengan kata-kata.

\section{Pembahasan}

Dari data yang dikumpulkan diketahui bahwa terdapat tiga jenis metafora sebagaimana disebutkan dalam teori imaji, yaitu metafora mental orientasi mental, metafora ontologi, dan metafora struktural. Berikut ketiga jenis metafora yang terdapat dalam metafora bencana alam banjir, gempa, dan gunung meletus.

\subsection{Metafora Orientasi Mental}

Dari data diketahui beberapa metafora tentang bencana alam termasuk ke dalam metafora orientasi mental. Berikut beberapa contoh metafora orientasi mental.

(1) Tingginya curah hujan di kawasan Pulau Jawa pada periode Desember 2013 hingga Februari 2014 menyebabkan tingginya risiko bencana banjir di berbagai wilayah di Pulau Jawa.

(2) Aktivitas tinggi Gunung Merapi membuat resah warga sekitar.

(3) Bahaya letusan Gunung Kelud tinggal di depan mata.

(4) Perumahan di sekitar sungai memiliki risiko tinggi kalau terjadi hujan kiriman.

(5) Jarak pandang di Solo pada pagi ini pendek akibat abu vulkanik yang disemburkan Gunung Kelud.

(6) Aktivitas Sinabung menurun, pengungsi dari 17 Desa dipulangkan.
Pada contoh (1), (2), dan (4) menggunakan kata tinggi sebagai metafora. Berdasarkan KBBI kata tinggi berarti jauh jaraknya dari posisi bagian atau sebelah bawah. Suatu benda dikatakan tinggi apabila dibandingkan dengan benda tingginya lebih kecil, misalnya hotel lima lantai $(200 \mathrm{~m})$ lebih tinggi dibandingkan dengan rumah satu lantai $5 \mathrm{~m}$. Namun, pada contoh (1) metafora tinggi digunakan untuk menunjukkan orientasi arah yang diterapkan pada kata hujan guna menggambarkan intensitas hujan yang sering terjadi. Pada contoh (2) pemanfaatan kata tinggi digunakan sebagai metafora berorientasi arah untuk menggambarkan aktivitas Gunung Merapi yang kemungkinan meletus setiap saat. Gajala-gajala meletus ditandai dengan seringnya Gunung Merapi mengeluarkan gas beracun, gempa, keluar suara gemuruh dari dalam perut gunung. Aktivitas yang terus-terusan terjadi merupakan tanda-tanda bahwa gunung akan meletus. Pada contoh (4) kata tinggi digunakan sebagai metafora berorientasi arah untuk menggambarkan bahaya yang dapat terjadi setiap saat dan kemungkinan besar bahwa orang yang tinggal di sekitar rumah akan mengalami kerugian baik materi dan nonmateri. Dengan demikian, kata tinggi pada contoh (1), (2), dan (4) memiliki kesamaan dalam hal menggambarkan situasi genting, darurat, dan bahaya.

Pada contoh (3) kata di depan mata termasuk ke dalam jenis metafora orientasi mental yang mengungkapkan jarak dan waktu letusan Merapi yang dekat atau sebentar lagi sehingga sulit untuk dihindari dampaknya apabila gunung meletus. Pada contoh (5) kata pendek termasuk dalam metafora orientasi mental karena kata pendek menunjukkan pengamatan indrawi terhadap suatu benda yang dikaitkan dengan jarak spatial atau arah. Dalam hal 
ini kemampuan memandang manusia ketika hujan abu. Hujan abu yang lebat menyulitkan bagi pengendara untuk dapat melihat dengan jelas sehingga disebut jarak pandang pendek. Pada contoh (6) digunakan metafora menurun, kata menurun termasuk ke dalam metafora orientasi mental karena menunjukkan arah yang merupakan perwujudan dari pengalaman kondisi mental yang menyatakan sesuatu aktivitas yang sudah tidak terjadi lagi atau jarang terjadi lagi. Aktivitas yang jarang terjadi atau tidak terjadi, yaitu aktivitas gejala letusan Gunung Sinabung seperti gempa, keluar magma, keluar lahar, dan lain-lain.

\subsection{Metafora Ontologi}

Berdasarkan hasil pengamatan, metafora ontologi berdasarkan tujuannya dibagi menjadi merujuk (reffering), menghitung (quantifying), menunjukkan aspek (identifying aspects), menunjukkan sebab (identifying causes), menunjukkan tujuan dan mendorong tindakan (setting goals and motivating actions).

\subsubsection{Merujuk (Reffering)}

Beberapa contoh metafora ontologis yang bertujuan merujuk sebagai berikut.

(1) Kepala Bidang Informatika dan Pengendalian Badan

Penanggulangan Bencana Daerah (BPBD) DKI Jakarta Edy Junaedi Harahap mengimbau warga di bantaran Kali Ciliwung waspada banjir kiriman.

(2) Meski begitu, kata Sujarwo, ada juga tetangga mereka yang yakin isi perut Gunung Kelud itu tidak akan menjangkau mereka.
(3) Seperti kembang api berwarna merah menyala, kata Qomarudin, warga Puncu.

(4) Meski aktivitas vulkanik gunung Kelud sudah menurun, teror terhadap pengungsi belum mereda.

(5) Mereka menyaksikan fenomena alam itu dengan degdegan karena mungkin pengalaman itu bisa mengakhiri hidup mereka.

Pada contoh (1) terdapat metafora banjir kiriman. Banjir kiriman mengacu pada banjir yang terjadi akibat curah hujan yang tinggi di daerah Bogor yang permukaannya lebih tinggi dibandingkan Jakarta. Air hujan yang lebat mengalir ke sungai-sungai yang mengarah ke daerah Jakarta sehingga mengakibatkan banjir. Aliran air yang berasal dari daerah Bogor disebut banjir kiriman karena dianggap dikirim oleh sungai berada di daerah yang lebih tinggi, yaitu kota Bogor. Pada contoh (2) terdapat metafora isi perut yang mengacu pada magma Gunung Kelud. Pada contoh 3 kembang api mengacu pada magma Gunung Kelud yang memancar ketika Gunung Kelud meletus. Pada contoh (4) kata teror digunakan untuk merujuk pada bahaya yang disebabkan setelah letusan Gunung Kelud meliputi lahar dingin dan debu vulkanik. Pada contoh (5) terdapat metafora degdegan yang mengacu pada suasana hati yang tidak nyaman karena rasa takut akan letusan Gunung Sinabung.

\subsubsection{Menghitung (Quantifying)}

Beberapa contoh metafora ontologis dengan tujuan menghitung sebagai berikut.

(1) Ia mengaku mendapatkan pengalaman luar biasa 
menyaksikan detik-detik letusan Gunung Kelud.

(2) Waktu sudah semakin habis karena sewaktu-waktu Kelud dapat meletus.

(3) Diperlukan banyak kesabaran warga bantaran kali untuk menghadapi banjir yang kerap melanda setiap tahun.

Pada contoh (1) terdapat metafora detik-detik yang menunjukkan hitungan jumlah waktu yang sedikit. Detik merupakan satuan waktu yang paling kecil, pengulangan kata detik menjadi detik-detik menunjukkan jumlah waktu yang sedikit atau hanya sebentar dan terkait dengan urutan peristiwa yang berlangsung cepat. Pada contoh (2) digunakan metafora yang menunjukkan jumlah, yaitu waktu sudah semakin habis. Metafora ini mengandung makna bahwa jumlah waktu yang tersisa semakin sedikit atau semakin dekat dengan peristiwa terjadinya letusan Gunung Kelud. Pada contoh (3) terdapat metafora banyak kesabaran, kesabaran merupakan kata abstrak yang menurut KBBI bermakna ketenangan hati dalam menghadapi cobaan; sifat tenang (sabar). Kata banyak kesabaran merujuk pada kemampuan untuk menahan cobaan atau ujian yang terjadi sering dan dalam jangka waktu lama.

\subsubsection{Menunjukkan Aspek (Identifying Aspects)}

Beberapa contoh metafora ontologis dengan tujuan menunjukkan aspek sebagai berikut.

(1) Kemarahan alam menjadi penyebab banjir bandang.

(2) Amukan Gunung Kelud menyisakan duka bagi para pengungsi.

(3) Hembusan napas Gunung Sinabung memakan korban jiwa.
Pada contoh (1) terdapat metafora kemarahan alam yang merujuk pada aspek bencana alam akibat kelalaian dan keserakahan manusia, yaitu tidak dapat memelihara dan menjaga alam lingkungan sekitarnya dengan cara menggunduli kawasan hutan di daerah dataran tinggi. Penggundulan hutan menjadi aspek yang mengakibatkan terjadinya longsor dan banjir bandang. Pada contoh (2) terdapat metafora amukan Gunung Kelud. Amukan merupakan kata nomina yang berdasarkan KBBI berarti serangan membabi buta yang dilakukan sekelompok manusia atau seseorang. Amukan mengikuti nomina bukan manusia, yaitu Gunung Kelud. Oleh karena itu, Gunung Kelud yang meletus diibaratkan sebagai makhluk hidup yang dapat marah membabi buta menghancurkan di sekitarnya karena material yang dikeluarkan saat letusan berupa awan panas, lahar, lava, dan lainlain merugikan masyarakat sekitarnya. Amukan Gunung Kelud ditempatkan sebagai aspek yang memberikan kesedihan bagi para pengungsi. Pada contoh (3) terdapat metafora hembusan napas Gunung Sinabung. Berdasarkan KBBI napas diartikan sebagai udara yang diisap melalui hidung atau mulut dan dikeluarkan kembali dari paru-paru dan hembusan diartikan sebagai keluar udara atau ditiupkan udara dari mulut atau hidung. Dengan demikian, kosakata napas dan hembusan khusus digunakan untuk makhluk bernyawa. Akan tetapi, penulis menggunakannya sebagai metafora aspek awan panas, gas panas, dan udara panas Gunung Sinabung yang meletus.

\subsubsection{Menunjukkan Sebab dan Akibat (Identifying Cause and Effect)}

Beberapa contoh metafora ontologis dengan tujuan menunjukkan aspek sebab dan akibat sebagai berikut. 
(1) Awan panas Sinabung menyebabkan 17 jiwa melayang.

(2) Banjir di ibukota mengakibatkan roda perekonomian lumpuh.

Pada contoh (1) terdapat metafora yang menunjukkan akibat, yaitu 17 jiwa melayang. Berdasarkan KBBI melayang berarti terbang (dengan sayap tidak bergerak); terbang karena dihembus angin tidak menentu dan tidak terarah. Dengan demikian, jiwa diasosiasikan sebagai hal yang dapat terbang dan menghilang atau dengan kata lain jiwa melayang dimaksudkan meninggal. Pada contoh (2) terdapat metafora yang menunjukkan akibat, yaitu roda perekonomian lumpuh. Perekonomian diibaratkan seperti roda yang dapat berputar dari posisi atas ke bawah dan sebaliknya. Perputaran ini menunjukkan kedinamisan ekonomi yang ditandai adanya transaksi, jual beli, pendapatan, dan lain-lain kemudian berhenti atau tidak ada perputaran yang diasosiasikan dengan kata lumpuh atau tidak bergerak sama sekali. Lumpuh perekonomian ditandai dengan tidak adanya transaksi, jual beli, pendapatan dan lain-lain karena tempat untuk transaksi terendam banjir selain itu pasokan komoditas perdagangan juga tidak berjalan.

\subsubsection{Menunjukkan Tujuan dan Mendorong Tindakan (Setting Goals and Motivating Actions)}

Beberapa contoh metafora ontologis dengan tujuan menunjukkan aspek sebab sebagai berikut.

(1) Para pengungsi mulai berdatangan ke tempat-tempat pengungsian untuk menghindari bangunnya Sinabung dari tidurnya yang lama.

(2) Warga di sekitar mengungsi berbondong-bondong untuk menyelamatkan diri dari hembusan napas maut Gunung Kelud.
Pada contoh (1) terdapat metafora yang menunjukkan tujuan, yaitu untuk menghindari bangunnya Sinabung dari tidurnya yang lama. Gunung Sinabung diibaratkan sebagai makhluk hidup yang dapat tidur dan bangun. Bangun dari tidur maksudnya Gunung Sinabung meletus lagi setelah lama tidak aktif (tidur). Pada contoh (2) terdapat metafora yang menunjukkan mendorong tindakan, yaitu untuk menyelamatkan diri dari hembusan napas maut Gunung Kelud. Napas merupakan verba yang mencirikan makhluk hidup sehingga letusan Gunung Kelud dianggap sebagaimana makhluk dapat bernapas (mengeluarkan awan panas berbahaya).

\subsection{Metafora Struktural}

Berdasarkan data diketahui bahwa beberapa metafora struktural berupa benda (banjir, gempa, dan letusan gunung) dipetakan sebagai makhluk hidup. Pemetaan dilakukan dengan mengidentifikasi topik dan wahana sebagaimana berikut ini.

\section{Topik \\ Banjir

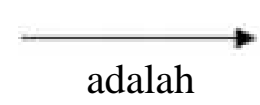 \\ Wahana
makhluk
hidup}

(1) Banjir melumpuhkan jalan

(2) Banjir bandang masih mengancam Situbondo;

(3) Banjir telah memakan korban jiwa.

Kata banjir diikuti dengan kata verba untuk makhluk bernyawa, yaitu melumpuhkan, mengancam, dan memakan. Banjir dipetakan sebagai makhluk hidup karena memiliki karakteristik sebagai makhluk hidup. Sementara itu, pemetaan yang sama juga terdapat pada topik letusan Gunung pada beberapa contoh berikut ini. 
Topik

Letusan

Gunung

(1) Sinabung yang batuk mengeluarkan awan panas.

(2) Letusan Kelud terjadi ketika Gunung Sinabung di Kabupaten Karo, Sumatra Utara belum lagi tenang --pascabangun dari tidur panjangnya selama 400 tahun.

(3) Letusan Merapi dan Kelud

bertanggung jawab atas ribuan kematian.

Kata letusan Gunung merupakan benda diikuti dengan verba untuk makhluk (manusia) meliputi batuk, tidur, dan bertanggung jawab. Berdasarkan pemetaan posisi letusan gunung sebagai topik dan wahananya adalah makhluk hidup. Pemetaan lainnya terdapat pada topik gempa dan wahananya sebagai makhluk hidup.

\section{Topik gempa

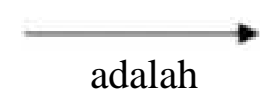 \\ Wahana makhluk hidup}

(1) Gempa memakan korban sebanyak 300 orang.

(2) Gempa bumi ini diperkirakan telah membunuh 52 orang dan melukai beberapa orang lainnya.

(3) Gempa tersebut menghilangkan 668 orang jiwa.

Kata letusan Gunung merupakan benda diikuti dengan verba khusus yang digunakan untuk makhluk (manusia) meliputi batuk, tidur, dan bertanggung jawab. Berdasarkan pemetaan posisi letusan gunung sebagai topik dan wahananya adalah makhluk hidup karena banjir memiliki karakteristik sebagai makhluk hidup.

\subsection{Sudut Pandang Pemakaian Metafora Bencana Banjir, Gunung Meletus, dan Gempa}

Berdasarkan pemetaan metafora terlihat bahwa topik yang meliputi bencana alam banjir, gunung meletus, dan gempa dipetakan dalam wahana sebagai makhluk hidup. Hal ini karena kata banjir, letusan gunung, dan gempa banyak diikuti verba yang mencerminkan memiliki kemampuan untuk berbuat sesuatu layaknya makhluk hidup, misalnya banjir melumpuhkan jalan ibukota; Banjir bandang masih mengancam Situbondo; banjir meninggalkan tumpukan sampah; banjir telah memakan korban jiwa; Sinabung batuk menyisakan duka; hembusan napas Sinabung memakan 17 jiwa; gempa membunuh 150 orang dan lain sebagainya.

Pemaknaan kata banjir, gunung meletus, dan gempa sebagai bencana alam melalui penggunaan metafora mencerminkan sudut pandang pembuat berita dan masyarakat terhadap bencana alam banjir, gunung meletus, dan gempa. Sudut pandang masyarakat menempatkan banjir, gempa dan letusan gunung sebagai fenomena alam yang memiliki kemampuan layaknya kekuatan yang hidup dan nyata dalam kehidupan masyarakat. Kekuatan tersebut dapat melakukan sesuatu yang memberikan bencana bagi manusia yang kemudian direkam dan dicerminkan dalam pemakaian metafora dengan menggunakan perumpamaan seperti makhluk bernyawa. Makhluk bernyawa (bencana alam) ini berkemampuan untuk membunuh, menghancurkan, melumpuhkan, memakan, mengancam, merusak, dan lain-lain sehingga mengakibatkan kerugian, kerusakan, korban, dan duka. Dengan demikian, penggunaan metafora merupakan suatu ekspresi yang mencerminkan daya tanggap dan pengamatan indrawi 
masyarakat untuk mengemukakan pandangannya dan pengetahuannya terhadap fenomena bencana alam (banjir, letusan gunung, dan gempa) sebagai kekuatan hidup yang memengaruhi kehidupan masyarakat sekitarnya.

\section{Simpulan}

Dari hasil temuan dan analisis dapat disimpulkan:

1. Metafora konseptual, yaitu metafora orientasional, ontologis, dan struktural telah digunakan untuk mengungkapkan bahasa bencana alam, misalnya bahaya letusan gunung sudah di depan mata.

2. Pemakaian metafora terkait bencana banjir, gempa, dan letusan gunung dapat dikatakan sebagai pola pikir dan cara pandang masyarakat terhadap bencana tersebut. Berdasarkan data diketahui penggunaan metafora dengan pemetaan topik bencana alam dan wahana karakteristik makhluk hidup sering digunakan, misalnya letusan gunung membunuh puluhan nyawa. Pemetaan metafora memberikan gambaran bahwa bencana alam (banjir, letusan gunung, dan gempa) sebagai makhluk hidup yang memiliki kekuatan untuk menghancurkan, membunuh, memakan korban, melumpuhkan, dll.

3. Penggambaran metafora sebagai makhluk hidup tersebut juga menjelaskan betapa manusia sebagai makhluk yang lemah ketika menghadapi bencana alam banjir, gempa, dan letusan gunung. Selain itu, metafora juga difungsikan untuk menggambarkan perilaku manusia yang lalai dalam memelihara alamnya. Kelalaian manusia tercermin dalam metafora kemarahan alam menyebabkan banjir bandang. Kemarahan alam merupakan metafora ontologis yang mengacu pada eksploitasi hutan sehingga menjadi hutan gundul sehingga ketika hujan lebat di dataran tinggi hutan menyebabkan terjadinya banjir bandang.

\section{Daftar Pustaka}

Andriani, Lati. 2013. "Analisis Metafora Pada Berita Olahraga dan Implikasinya bagi Pembelajaran Bahasa Indonesia di SMA :Kajian Deskriptif Analitik terhadap Berita Olahraga dalam Surat Kabar di Indonesia”. Tesis. Universitas Pendidikan Indonesia.

Danesi, M dan Perron, P. 1999. Analyzing Cultures: An Introduction and Handbook. USA: Indiana University Press.

Kamus Besar Bahasa Indonesia. 2008. Jakarta: Balai Pustaka.

Kridalaksana, Harimurti. 2001. Kamus Linguistik. Jakarta Gramedia.

Lakoff, George dan Mark Johnson. 2003. Methaphors We Live By. Chichago dan London: University of Chicago Press.

Ullmann, Stephen. 2007. Sumarsono (penj.). Pengantar Semantik. Yogyakarta: Pustaka Pelajar.

Ungerer, F dan H. J. Schimd, 1996. An Introduction to Cognitive Linguistics. London: Longman.

Satriyo, Joko. 2008. "Metafora untuk Kata Kalah dan Menang dalam Tajuk Berita Olahraga di Surat kabar. Fakultas Ilmu Pengetahuan Budaya". Skripsi. Universitas Indonesia.

Saeed, John I, 2003. Semantics. Second Edition. Oxford: Blackwell Publishing. 


\section{Sumber Data}

http://news.liputan6.com/read/833157/rel awan-ugm-mendata-ulang-wargamiskin-di

kudus\#sthash.d8871PAy.dpuf, diakses Januari 2014.

http://news.liputan6.com/read/833157/rel awan-ugm-mendata-ulang-wargamiskin-di-kudus, diakses Januari 2014 http://news.liputan6.com/read/813992/ko misi-v-dpr-ri-kunjungi-desa-bugelyangterendambanjir?news.trkn\#sthash.xiLi htkZ.dpuf, diakses Januari 2014.

http://news.liputan6.com/read/808661/pu ncak-bogor-hujan-berkabut-jarakpandang-5-

meter\#sthash.6SOsVw0c.dpuf, diakses Januari 2014.

http://www.ibnurusydy.com/geobencana/debris-flow-banjirbandang/\#ixzz34la8Sqni, diakses Januari 2014.

http://www.ibnurusydy.com/waspadabencana-di-musimpenghujan/\#ixzz34lnpZSAP, diakses Januari 2014.

http://www.ibnurusydy.com/bencanaalam-gempa-bumi-terdahsyat-di-abadke-21/\#ixzz34luyRrL3, diakses

Februari 2014.

http://www.ibnurusydy.com/7-bencanaalam-gempa-bumi-mematikan-dalamsejarahmanusia/\#ixzz34lvsaeJs, diakses Februari 2014.

http://news.liputan6.com/read/828929/lih at-jejak-letusan-dahsyat-gunungindonesia-yangdipantaunasa\#sthash.ewfscNea.dpuf, diakses Maret 2014.

http://news.liputan6.com/read/826639/let usan-kelud-bahaya-yang-mengintaidari-ring-of fire\#sthash.QyLCqg15.dpuf, diakses Maret 2014.

http://news.liputan6.com/read/828195/he batnya-letusan-gunung-kelud-dilihat-
dari-angkasa\#sthash.EW5T9ywl.dpuf, diakses April 2014.

http://news.liputan6.com/read/826615/let usan-gunung-kelud-dari-masa-kemasa\#sthash.fFxpm0Xt.dpuf, diakses April 2014. 